\title{
Genetic and phenotypic analysis of daily Israeli Holstein milk, fat, and protein production as determined by a real-time milk analyzer
}

\author{
J. I. Weller*1 and E. Ezra† \\ *Institute of Animal Sciences, Agricultural Research Organization, The Volcani Center, Bet Dagan 50250, Israel \\ †lsrael Cattle Breeders Association, Caesaria Industrial Park 38900, Israel
}

\begin{abstract}
The objective was to test the hypothesis that more frequent but less accurately analyzed milk components may give a more representative measure of a cow's total lactation production. Daily records for milk production and fat and protein concentration collected by the AfiLab recording system (Afimilk, Kibbutz Afikim, Israel) from January 2014 to January 2016 from 47 large kibbutz (communal) herds distributed throughout Israel with a total of 37,486 Israeli Holstein cows were compared with the same statistics derived from monthly test day records derived by Bentley and Foss milk analyzers at the central laboratory of the Israel Cattle Breeders Association. The lactation means for all traits were quite similar for the 2 methods in both parities, except for fat production, which was lower for the daily records. This finding corresponded to fat lactation curves, which showed that daily results were lower with low days in milk (DIM) but almost equal to the monthly results after 125 DIM. Relative to monthly records, daily records overestimated protein percentage before 150 DIM and underestimated protein percentage in the second half of the lactation. The standard deviation for first- and second-parity daily records scored by the monthly and daily system were least similar for fat percentage, but even for this trait the difference was no more than 0.1 percentage points. The standard deviations for complete lactation production were slightly lower for the daily results for all traits but protein production. First-parity heritabilities were higher for lactations computed from daily records for all traits except for protein percentage, but differences were not significant. For daily records, coefficients of determination to predict future milk, fat, and protein lactation production from truncated lactations were greatest and root mean squared errors were least if the mean production from the last 2 weeks before the truncation date was used to estimate future production. Daily
\end{abstract}

Received March 10, 2016.

Accepted August 12, 2016.

${ }^{1}$ Corresponding author: joel.weller@mail.huji.ac.il first-parity partial lactations for milk, fat, and protein production with $<150$ DIM predicted future lactation more accurately than corresponding monthly partial lactations. With only 30 DIM, genetic correlations between predicted and actual lactations ranged from 0.73 to 0.79 for milk, fat, and protein production. Real-time daily recording of fat and protein concentration by the daily recording system may be preferable to monthly analysis for herd-management decisions and genetic evaluation. Further study is required to compare the results of individual cows in multiple lactations.

Key words: milk analysis, genetic analysis, daily fat recording, daily protein recording

\section{INTRODUCTION}

Daily automatic milk recording is now commercially available from several systems, but not for milk components. Generally, farmers and national genetic evaluation systems in the United States rely on the DHIA to determine individual milk composition. The DHIA provides monthly or less frequent analyses of individual cows' milk for fat and protein content and SCC. Milk components vary from milking to milking depending on time between milkings, DIM, season, and the cow's age, parity, and health (Quist et al., 2008; Pavel and Gavan, 2011). Recently, real-time analysis of milk components per cow per milking has become more widely available, primarily through implementation of automatic milking systems (Rotz et al., 2003). The AfiLab recording system (Afimilk, Kibbutz Afikim, Israel) is a real-time individual cow milk analyzer that is implemented per parlor stall. Each unit uses near-infrared spectroscopy for inline milk analysis (Tsenkova et al., 1999). The advantages of near-infrared spectroscopy over other systems are that they are quick and give nondestructive inline measurements (Schmilovitch et al., 2000). Accuracy may be reduced, however (Tsenkova et al., 2000). The AfiLab recording system provides observations of milk fat, protein, and lactose components, in addition to the amount of blood.

Kaniyamattam and De Vries (2014) compared AfiLab analyzer results for fat, protein, and lactose concentra- 
tion in 450 cows from the University of Florida Dairy Unit with results collected on 23 DHIA test days in 2010 and 2011, measured with the Bentley 2000 analyzer (Bentley Instruments Inc., Chaska, MN), which uses mid-infrared spectrum light. The authors concluded that AfiLab slightly overestimated low Bentley components and underestimated high Bentley components. However, the accuracy of the Bentley analyzer is affected by instrument factors, the quality of the reference chemistry, characteristics of the calibration sample set, and individual milk sample composition factors (Kaylegian et al., 2006). Because neither method can be considered a "gold standard," we do not know how either system actually compares to the true values. All that could be determined with certainty in the Kaniyamattam and De Vries (2014) study was the similarity between the 2 methods. They conclude, "Given the day-to-day variation in milk components, especially fat, the milk components measured in just 1 milking per month may not be very representative of the milk produced during that entire month ... The combination of much more frequently but less accurately analyzed milk components, such as averaging all daily observations obtained per milking over a period for a cow, may give a more representative measure of a cow's longer-term milk composition than a DHIA sample taken once per month."

When a new analysis method cannot be compared with a gold standard method, other alternatives for evaluation must be considered (e.g., Kaniyamattam and De Vries, 2014). One option is to compare heritabilities for the new and standard methods; another is to compare the ability of the 2 methods to predict complete lactation production from truncated lactation records. The question of systematic biases should also be addressed: is the new system biased for certain cows, or for other factors, such as stage of lactation, parity, or season?

Answering these questions requires much larger samples than that of Kaniyamattam and De Vries (2014). The primary objective of this study was to test their hypothesis that much more frequent, but less accurate analysis of milk components may give a more representative measure of a cow's total lactation production. The secondary objective was to determine whether systematic biases exist in the daily analysis system.

\section{MATERIALS AND METHODS}

\section{Farms, Cows, and Daily Records}

We analyzed daily records for milk production and fat and protein concentration collected from January
2014 to January 2016 from 47 large kibbutz (communal) herds distributed throughout the country ( $\mathrm{n}=$ 37,486 cows). All of these farms use NOA, a comprehensive program for dairy herd management developed and maintained by the Israeli Cattle Breeders' Association (ICBA), that addresses all aspects of dairy farming. Herd management was typical for kibbutz herds in Israel (Ginsberg, 2015). All cows were daughters of Israeli Holstein cows. Almost 96\% were daughters of Israeli progeny-tested bulls; $3.7 \%$ were progeny of foreign Holstein bulls, and the remaining $0.3 \%$ were daughters of foreign bulls from other breeds or bulls bred on-farm. Almost all cows were milked 3 times daily. Milk production and fat and protein concentration were recorded for each milking. Calibration of the automatic recording units against the standard ICBA milk recording system was done at least once for each 6-month period, and at least 7 cows were used to calibrate each unit. Daily milk production was the sum of production for the 3 milkings, beginning with the morning milking of each day. Daily fat and protein percentage was computed as the means of the 3 milking records weighted by the production for each milking. Records were included in the analysis if (1) DIM $>4$ and $<306,(2)$ percentage fat $>1.0$ and $<8,(3)$ percentage protein $>1.0$ and $<7$, and (4) daily milk production $>5$ and $<80 \mathrm{~kg}$. Only records that met all 4 criteria were retained.

\section{ICBA Data Recording}

The ICBA was awarded the International Committee for Animal Recording (ICAR) Certificate of Quality in 2012 for dairy cattle identification, production recording in dairy cattle, and genetic evaluation in dairy cattle. Daily fat and protein concentration records are not ICAR-certified. Standard recording in Israel is probably more accurate than in most other countries, because each month on the test day the milk inspector collects samples from 2 of 3 milkings. The most common strategy is alternate a.m./p.m. sampling, the main method used in the United States (Bucek et al., 2015). Visits in Israel are arranged so that a different milking is missed in each consecutive visit. With respect to milk production for farms with the daily recording system, the daily records from 3 daily milkings were summed, beginning with the first one observed by the inspector. Thus, for the ICBA record system, the "daily" milk production can start with the morning, afternoon, or night milking. Samples were collected from each cow for fat, protein, and SCC analysis from the 2 milkings during the inspector's visit and mixed in proportion to the milk produced by the cow in each of the 2 milkings, although the accuracy of this procedure is approximate 
at best. The inclusion criteria for the automatically recorded daily records were also applied to the ICBA records.

Milk components were analyzed in the Central Milk Laboratory of the ICBA in Caesarea using a CombiFoss (Foss, Hillerød, Denmark) and a Bentley FTS/FCM (Bentley Instruments, Inc., Chaska, MN). The Bentley FTS/FCM is made up of 2 separate modules: a flow cytometer and a Fourier transform spectrometer. The Fourier transform spectrometer simultaneously measures milk composition, including fat, protein, lactose, and urea, using Fourier transform infrared spectroscopy to capture the complete infrared absorption spectrum of the milk sample for component analysis. Collecting the complete spectrum allows the calibration to be based on all spectral characteristics of each particular component. The CombiFoss includes the MilkoScan FT+ and the Fossomatic FC. The MilkoScan FT+ estimates the concentration of urea, fat, protein, fatty acids, and lactose, based on Fourier transform infrared spectroscopy analysis. It works with the mid-infrared region of the spectrum from 3 to $10 \mu \mathrm{m}$, corresponding to 1,000 to $5,000 \mathrm{~cm}^{-1}$. The CombiFoss analyzes slightly more samples per day than the Bentley FTS/ FCM. The ICBA laboratory also has 2 additional less efficient Foss machines for backup. Overall, about 30\% of the samples were analyzed using the Bentley machine, and the remainder using the 3 Foss machines.

For both automatic daily and monthly records, fat production at each date was computed as fat percentage $\times$ milk production/100. Similarly, protein production at each date was computed as protein percentage $\times$ milk production/100. All data were stored in the ICBA central computer, which calculated total lactation milk, fat, and protein production for all milk-recorded cows.

\section{Computation of Total Lactation Production}

Lactation Computation for Daily Records. Milk, fat, and protein production up to 305 DIM were computed from the automatic daily records for first and second parities provided the following conditions were met: (1) first record in the lactation $\leq 10 \mathrm{~d}$ after parturition, (2) last record $\geq 255 \mathrm{~d}$ after parturition, and (3) period between consecutive records $<30 \mathrm{~d}$.

The second criterion was applied under the assumption that $255 \mathrm{~d}$ was likely to be the minimum lactation length for cows that were not culled. This corresponded with the expected lactation for a cow with $45 \mathrm{~d}$ open. The third condition was required because for 32 of 14,048 complete lactations, records were missing for extended periods due to technical problems. Milk, fat, and protein production up to the first record per lactation was assumed equal to the first valid daily record.
After the first record, the production per each interval was computed as the mean of the 2 records bordering the number of days between intervals for all records $\leq 305$ DIM. Lactations with last records $<305$ DIM were not extended beyond the last valid record.

Lactation Computation for Monthly Records. First- and second-parity lactations that met the following criteria were computed from the monthly data: (1) first lactation record $\leq 65$ DIM, (2) last lactation record $\geq 255$ DIM, and (3) interval between consecutive records $\leq 75 \mathrm{~d}$.

Up to 120 DIM, milk, fat, and protein production were computed as the integral of the standard lactation curve for the 3 traits, as described by Bar-Anan et al. (1984). From 120 DIM to the last record before 305 DIM, production was computed as the mean of the 2 records bordering the interval times between records. If the last valid record was $<305$ DIM, then production from the last record to the end of the lactation, or 305 DIM (whichever was lower), was assumed equal to production at the last record. Only the ICBA records were extended, assuming that automatic daily records should have captured production up to the end of the lactation. If a valid record >305 DIM was available, then production up to 305 DIM was computed, assuming that the lactation curve was linear between the last record before 305 DIM and the first record after 305 DIM.

\section{Statistical Analysis}

A total of 77,581 first-parity and 58,723 secondparity valid records were available for the same days for both daily and monthly recording methods (Table 1 ). Correlations for milk, fat, and protein production, and fat and protein percentage were computed for these records. Only valid lactations computed by both systems were included in the analysis. First- and second-parity daily and monthly lactation curves were computed as the mean production on each day from 5 through 305 DIM. The number of daily and monthly records and cows used to compute the lactation curves are given in Table 1. A total of 7,953 first-parity and 6,051 second-parity valid lactation records were available. We computed means and correlations between daily and monthly first- and second-parity lactation production for milk, fat, and protein production, and for fat and protein percentage.

Following Weller and Ezra (2004), before estimation of variance components and extension factors, firstparity lactation records were adjusted for the effects of calving month and age, days open, and pregnancy status (open or pregnant). The effects of these factors were computed using PROC GLM in SAS (version 9.2; 
Table 1. Number of records and levels of effects included in each analysis

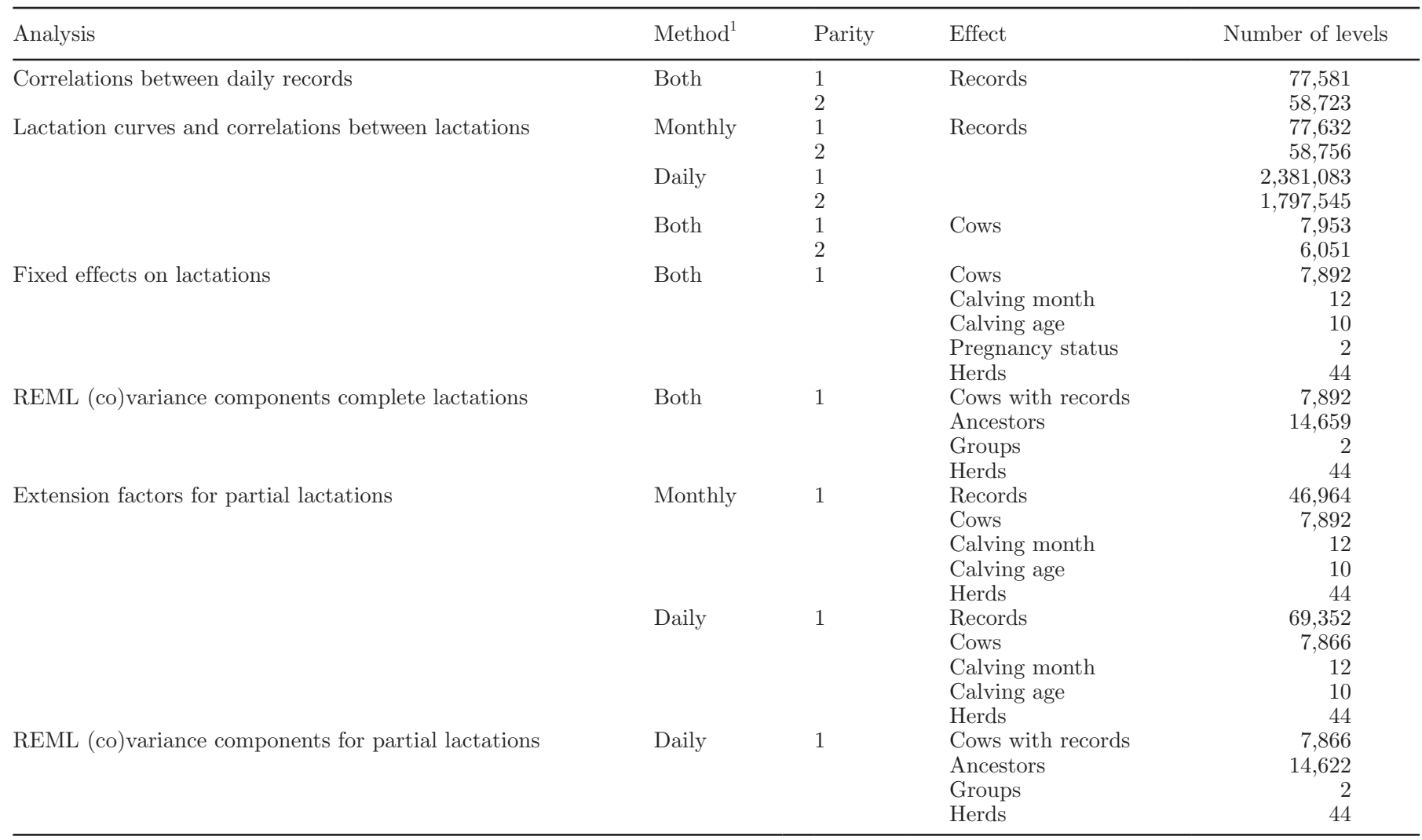

${ }^{1}$ Daily, monthly, or both.

SAS Institute Inc., Cary, NC). Milk, fat, and protein production, and fat and protein percentage, either daily or monthly, were analyzed separately. The analysis model was:

$$
\begin{aligned}
\mathrm{Y}_{\mathrm{ijklmn}} & =\mu+\mathrm{H}_{\mathrm{j}}+\mathrm{C}_{\mathrm{k}}+\mathrm{A}_{\mathrm{l}}+\mathrm{P}_{\mathrm{m}}+\mathrm{a} \times \mathrm{SDO} \\
& +\mathrm{b} \times \mathrm{DO}+\mathrm{c} \times \mathrm{DO}^{2}+\mathrm{e}_{\mathrm{ijklmn}},
\end{aligned}
$$

where $\mathrm{Y}_{\mathrm{ijklmn}}$ was lactation record $\mathrm{n}$ for trait $\mathrm{i}$, from herd $\mathrm{j}$, with calving month $\mathrm{k}$, calving age 1 , and pregnancy status $\mathrm{m} ; \mu$ was the intercept; $\mathrm{H}_{\mathrm{j}}$ was the effect of herd $\mathrm{j} ; \mathrm{C}_{\mathrm{k}}$ was the effect of calving month $\mathrm{k} ; \mathrm{A}_{1}$ was the effect of calving age $1 ; \mathrm{P}_{\mathrm{m}}$ was the effect of pregnancy status $\mathrm{m}$ (open or pregnant); SDO was the square root of days open; DO was days open; $\mathrm{DO}^{2}$ was the square of days open; a, b, and c were regression coefficients; and $\mathrm{e}_{\mathrm{ijk} k \mathrm{mn}}$ was the residual. This is similar to the model used for routine genetic evaluation of production traits in Israel (Weller and Ezra, 2004). All effects were assumed fixed, except for the residual. In Israel, all cows that are inseminated are checked for pregnancy $\sim 45 \mathrm{~d}$ after the last insemination of the lactation. We computed days open as described by Weller et al. (1985), and all
3 DO terms were required to accurately describe the effect of days open on production traits. For cows that were not pregnant, $\mathrm{DO}=0$, and the expected increase in production was included in the $\mathrm{P}_{\mathrm{m}}$ effect. Cows with calving age $<21 \mathrm{mo}$ and $>30$ mo were excluded. Of 7,953 cows with valid first-parity lactation records, 7,892 cows were included in the general linear model and REML analyses. The number of levels of effects included in the model are given in Table 1. All effects included in the models for all traits were significant $(P$ $<0.001)$.

Variance and covariance components were computed for daily and monthly first-parity adjusted lactations using MTC software (http://nce.ads.uga.edu/ ignacy/ numpub/mtc/), including all 10 traits. The MTC program uses a REML algorithm to compute variance and covariance components based on the multi-trait individual animal model (e.g., Weller and Ezra, 2004). All animals with records must have records for all traits included in the analysis. The relationship matrix included all known parents and grandparents of cows with records. In addition to the 7,892 cows with records, the relationship matrix included 14,659 ancestors, for a total of 22,551 animals. Two groups were defined 
for individuals with parents that were not included in the relationship matrix: 1 for males and 1 for females. In addition to the additive genetic and group effects, the analysis model included a fixed herd effect. The number of levels of all effects included in the model are also given in Table 1 . Heritabilities for each trait were computed as the additive genetic effect divided by the sum of the additive genetic and residual effects. Genetic and environmental correlations were computed for all pairs of traits.

Variance and covariance components were also computed using AIREMLF90 (http://nce.ads.uga. edu/wiki/doku.php?id=application_programs). We ran a separate analysis for each trait computed from daily and monthly records, because convergence was not obtained when all traits were run jointly. Thus, covariance components were estimated only between the daily and monthly lactation records for each trait. The AIREMLF90 program, in addition to estimates of the variance and covariance components, computes $\mathrm{SE}$ and the inverse of the average information matrix. Approximate SE for the heritabilities and the genetic correlations were derived using the algorithm of Klei (2008). Heritabilities in all cases were similar to the estimates derived by MTC.

To compare the ability of the 2 methods to predict future lactation production from truncated lactation records, we computed extension factors for partial lactations as follows. The complete adjusted lactations computed from the automatic daily records for milk, fat, and protein production were truncated after each complete month in milk up to the ninth month. The truncation point for each month in milk was the first valid daily record after each complete month in milk. Thus, up to 9 partial lactation records were generated from each complete lactation record.

To obtain approximately equal DIM for the corresponding cohort of truncated monthly records, monthly records were truncated at the first valid record obtained after $15 \mathrm{~d}$ before each complete month in milk. That is, the truncation points were at the first record after 15 , 45 , and 75 DIM, and so on. The numbers of truncated records generated for the monthly and daily adjusted lactations are given in Table 1. Fewer truncated records were generated for the monthly records, because in some cases more than 1 mo had elapsed between consecutive records, resulting in a "missing" truncated record for a specific month in milk.

As proposed by Weller (1988), we computed extension factors using PROC GLM in SAS (version 9.2; SAS Institute, Inc.) with remaining lactation production after the truncation point as the dependent variable. The analysis model for each trait for both monthly and daily adjusted lactation was:

$$
\begin{gathered}
\mathrm{Y}_{\mathrm{ijklm}}=\mu+\mathrm{H}_{\mathrm{j}}+\mathrm{a} \times \mathrm{DR}+\mathrm{b} \times \mathrm{DR} \times \mathrm{C}_{\mathrm{k}}+\mathrm{c} \\
\times \mathrm{DR} \times \mathrm{A}_{1}+\mathrm{d} \times \mathrm{DR}^{2}+\mathrm{f} \times \mathrm{LR} \times \mathrm{DR}+\mathrm{g} \times \mathrm{LR}^{2} \\
\times \mathrm{DR}+\mathrm{n} \times \mathrm{DR} \times \mathrm{DIM}+\mathrm{o} \times \mathrm{DR} \times \mathrm{DIM}^{2} \\
+\mathrm{p} \times \mathrm{DR} \times \mathrm{DP}+\mathrm{q} \times \mathrm{DR} \times \mathrm{DP}^{2}+\mathrm{e}_{\mathrm{ijklm}}, \quad[2]
\end{gathered}
$$

where $Y_{\mathrm{ijklm}}$ was the remaining production in the lactation; DR was days remaining in the lactation; LR was the last valid daily record before truncation; DIM was DIM at the truncation point; DP was days pregnant at the truncation date; a, b, c, d, f, g, n, o, p, and $q$ were regression coefficients and the other terms were as defined for equation [1]. Various models were tested, but results are presented only for the model of equation [2], because all factors included in equation $[2]$ were significant $(P<0.001)$ in the daily analyses. Cows that were pregnant for $<30 \mathrm{~d}$ at the truncation point were assumed to be open; for these cows, DP = 0 . We computed DR as $305-$ DIM. If DP $>0$, then DR $=210-\mathrm{DP}$, assuming that pregnant cows would be dried off $210 \mathrm{~d}$ after conception. If DR + DIM $>305$, then $\mathrm{DR}=305-\mathrm{DIM}$. The lactations computed from daily records were also analyzed using a model that included the effects of LR and the daily record before LR, and with models that included mean production 1 week, 2 weeks, and 1 month before the truncation point, instead of LR.

We compared models based on their coefficients of determination and root mean square errors. We also computed means and standard deviations (SD) by months in milk at truncation to estimate accuracy and precision. Finally, we computed correlations between complete lactation yields and predicted yields as production before truncation + predicted production after the truncation point, as computed using the effects in equation [2]. We also computed variance and covariance components between daily complete and predicted lactations using MTC. Only predicted lactations based on months 1 to 8 were included, because some lactations were completed before 9 mo in milk. The model included the same effects as for complete lactations. The number of cows, ancestors, herds, and groups are given in Table 1. Variance components were not computed for the monthly records, because as noted previously, truncated records were not generated for all months in milk for all cows, and MTC requires valid records for all traits for all individuals with records.

\section{RESULTS AND DISCUSSION}

Means, SD, and correlations between daily milk, fat, and protein, and fat percentage and protein percentage, computed from the monthly and daily recording 
in first and second parities are given in Table 2. As expected, means and SD were very similar for milk, and correlations were $\geq 0.95$, because both methods were based on the same individual milking records. The only difference was that for automatic daily recording the "day" always began with the morning milking, but for the ICBA (monthly) records the "day" began with the first milking attended by the inspector. Differences between means were very small for all traits, but this was partially a function of how often the meters were calibrated, and what samples were used for calibration. Despite the small absolute values, all differences were significant $(P<0.01)$ because of the huge sample sizes. Overall, the SD for the 2 methods were quite similar. The greatest difference was for fat percentage, where differences were 0.09 and $0.1 \%$ in parities 1 and 2 , respectively. All correlations were slightly higher in second parity. The correlations for fat and protein production were higher than for fat and protein percentage. However, the correlation for protein percentage was lower than for fat percentage, but the correlation for protein production was higher than for fat production. This was likely because protein percentage had a lower SD than fat percentage. Liu et al. (2000) found for German Holsteins that correlations between the a.m. and p.m. records of the same cows were 0.59 for fat percentage, but $>0.8$ for the other 4 traits.

Means, SD, and correlations between 305-d milk, fat, and protein production, and fat percentage and protein percentage, computed from the monthly and daily recording in first and second parities are given in Table 3. As expected milk, fat, and protein production were higher in second parity, but fat percentage was slightly lower. All differences in the means between the 2 methods were significant $(P<0.001)$, except for first-parity milk and protein yield. Monthly mean fat production and percentage were higher than the corresponding daily means in both parities. The SD for complete lactation production were slightly lower for the daily results for all traits, except protein production. All correlations between lactations were higher than the correlations between records for daily production. Correlations for first and second parity were very similar for all traits. As found for the daily records, correlations were higher for fat and protein production, than for fat and protein percentage. Correlations for fat and protein production were 0.77 and $\sim 0.9$ in both lactations. With respect to most commercial selection indices, these are the actual traits of interest (Miglior et al., 2005).

Mean first- and second-parity lactation curves for milk, fat, and protein production by monthly test days and daily records are shown in Figures 1, 2, and 3 . As expected for milk production, the curves for the 2 methods are very similar for both parities, except that the monthly curves display more random variation because of the lower number of records for each date. Similar to all previous analyses (e.g., De Boer et al., 1989), second-parity milk production peaks earlier and higher than first parity. Fat production in first parity reaches a maximum level at $\sim 75$ DIM and remains stable until 305 DIM. In second parity, maximum production is obtained at $\sim 25$ DIM and declines linearly until 305 DIM. For both parities, the graphs based on the monthly records were higher before 125 DIM, but very similar for both methods from 125 through 305 DIM. The maximum difference was $0.1 \mathrm{~kg}$ for first parity and $0.18 \mathrm{~kg}$ for second parity. The graphs based on the monthly records for protein were quite similar to the corresponding graphs for milk. In both parities, the daily records overestimated protein production in the early part of the lactation and underestimated production after 150 DIM. The maximum difference was 0.08 $\mathrm{kg}$ for both parities.

Mean first-parity lactation curves for fat and protein percentage by monthly and daily records are given in Figure 4, and the corresponding curves for second parity are given in Figure 5. Corresponding to the graphs for

Table 2. Means $\pm \mathrm{SD}^{1}$ and correlations between daily milk, fat, and protein, and fat and protein percentage from monthly and daily records in first and second parities

\begin{tabular}{llrrc}
\hline Parity & Trait & \multicolumn{1}{c}{ Monthly } & \multicolumn{1}{c}{ Daily } & Correlation $^{2}$ \\
\hline $1(77,581$ records) & Milk (kg/d) & $35.11 \pm 6.09$ & $34.98 \pm 6.15$ & 0.95 \\
& Fat (kg/d) & $1.25 \pm 0.23$ & $1.24 \pm 0.21$ & 0.67 \\
& Protein (kg/d) & $1.13 \pm 0.18$ & $1.14 \pm 0.20$ & 0.83 \\
& Fat (\%) & $3.62 \pm 0.58$ & $3.57 \pm 0.49$ & 0.62 \\
$2(58,723$ records) & Protein (\%) & $3.25 \pm 0.26$ & $3.26 \pm 0.24$ & 0.42 \\
& Milk (kg/d) & $41.45 \pm 8.78$ & $41.24 \pm 8.81$ & 0.96 \\
& Fat (kg/d) & $1.45 \pm 0.32$ & $1.44 \pm 0.29$ & 0.72 \\
& Protein (kg/d) & $1.34 \pm 0.24$ & $1.33 \pm 0.28$ & 0.87 \\
& Fat (\%) (\%) & $3.55 \pm 0.64$ & $3.54 \pm 0.54$ & 0.62 \\
& Protein (\%) & $3.26 \pm 0.31$ & $3.24 \pm 0.25$ & 0.48 \\
\hline
\end{tabular}

${ }^{1}$ All differences between the means of the 2 methods were significant, $P<0.01$.

${ }^{2}$ All standard errors of the correlations were $\leq 0.01$. 
Table 3. Means $\pm \mathrm{SD}^{1}$ and correlations between 305-d milk, fat, and protein, and fat and protein percentages from monthly and daily records in first and second parities

\begin{tabular}{llccc}
\hline Parity & Trait & Monthly & Daily & Correlation $^{2}$ \\
\hline $1(7,953$ cows) & Milk (kg) & $10,472 \pm 1,303$ & $10,440 \pm 1,293$ & 0.97 \\
& Fat (kg) & $376 \pm 49$ & $369 \pm 47$ & 0.77 \\
& Protein (kg) & $339 \pm 39$ & $340 \pm 41$ & 0.90 \\
& Fat (\%) & $3.61 \pm 0.39$ & $3.55 \pm 0.30$ & 0.67 \\
$2(6,051$ cows) & Protein (\%) & $3.24 \pm 0.16$ & $3.26 \pm 0.14$ & 0.56 \\
& Milk (kg) & $12,432 \pm 1,599$ & $12,301 \pm 1,556$ & 0.97 \\
& Fat (kg) & $439 \pm 63$ & $429 \pm 59$ & 0.77 \\
& Protein (kg) & $402 \pm 47$ & $397 \pm 50$ & 0.89 \\
& Fat (\%) & $3.55 \pm 0.42$ & $3.50 \pm 0.33$ & 0.65 \\
& Protein (\%) & $3.24 \pm 0.17$ & $3.23 \pm 0.15$ & 0.57 \\
\hline
\end{tabular}

${ }^{1}$ All differences in the means were significant $(P<0.001)$, except for first-parity milk and protein yield.

${ }^{2}$ All standard errors of the correlations were $\leq 0.01$.

fat and protein production, the daily results underestimated fat percentage in the early part of the lactation, but were very similar to the monthly results after 125 DIM. The maximum difference at the beginning of the lactation was $0.4 \%$ for first parity and $0.6 \%$ for second parity. Considering the entire lactation, we observed only a slight decrease in the means of fat percentage for individual daily records or total lactation production (Tables 2 and 3 ).

The daily results overestimated protein percentage in the first part of the lactation, but underestimated it after 150 DIM. Over the entire lactation, these 2 biases almost canceled out, and lactation means for both protein yield and percentage were almost equal for both methods. The maximum difference at the beginning of the lactation was $0.3 \%$ for first parity and $0.4 \%$ for second parity. These results can be partially explained by the finding of Kaniyamattam and De Vries (2014) that "AfiLab slightly overestimated low Bentley components and underestimated high Bentley components." With respect to protein, the daily records overestimated protein percentage during the first part of the lactation when protein was low, and underestimated protein percentage in the later part of the lactation when percentage was higher. Fat percentage was lowest at $\sim 50$ DIM in both parities, but at this point, the daily results were lowest relative to the monthly records.

Heritabilities and genetic and environmental correlations among 7,892 first-parity adjusted records for 305-d milk, fat, and protein production and fat and

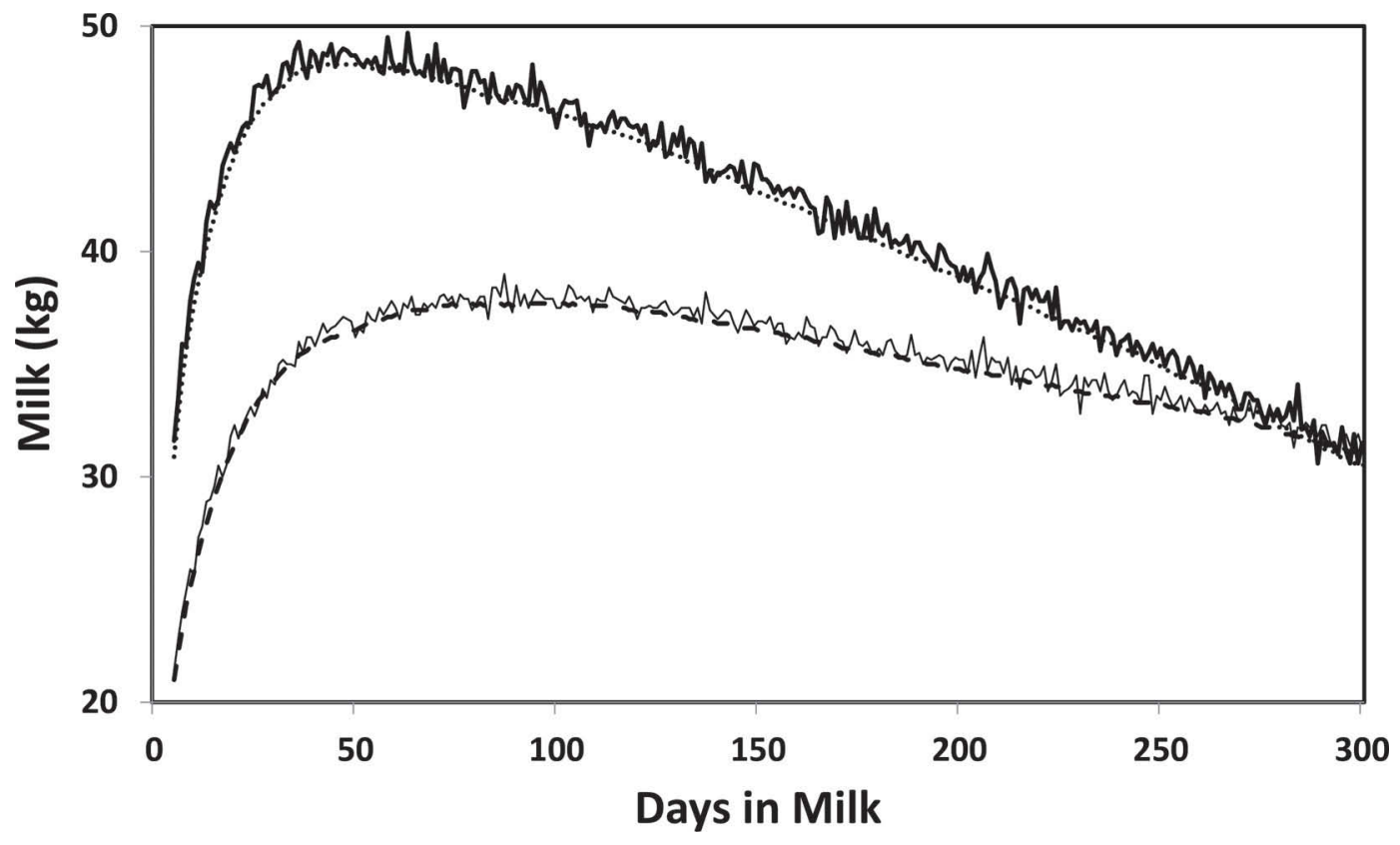

Figure 1. Mean first- and second-parity lactation curves for milk production by monthly and daily records. First-parity monthly records, light solid line; first-parity daily records, dashed line; second-parity monthly records, heavy solid line; second-parity daily records, dotted line. 


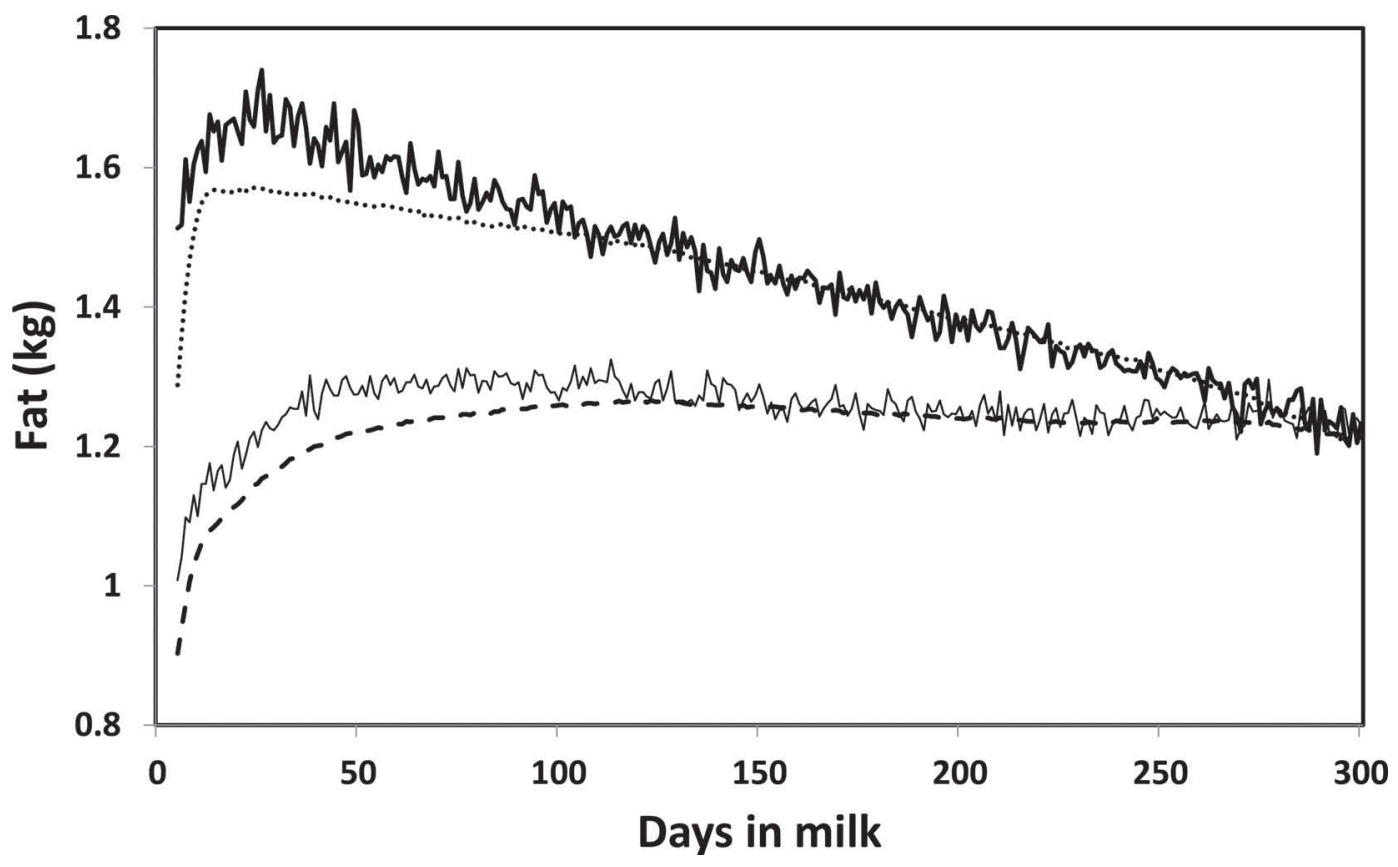

Figure 2. Mean first- and second-parity lactation curves for fat production by monthly and daily records. First-parity monthly records, light solid line; first-parity daily records, dashed line; second-parity monthly records, heavy solid line; second-parity daily records, dotted line.

protein percentage computed from monthly and daily records are given in Table 4 . The approximate SE of the heritabilities and genetic correlation estimates are also given. Heritabilities were $\sim 0.3$ for the production traits, and $\sim 0.5$ for the percentage traits. In general, the results were similar to previous sire and individual

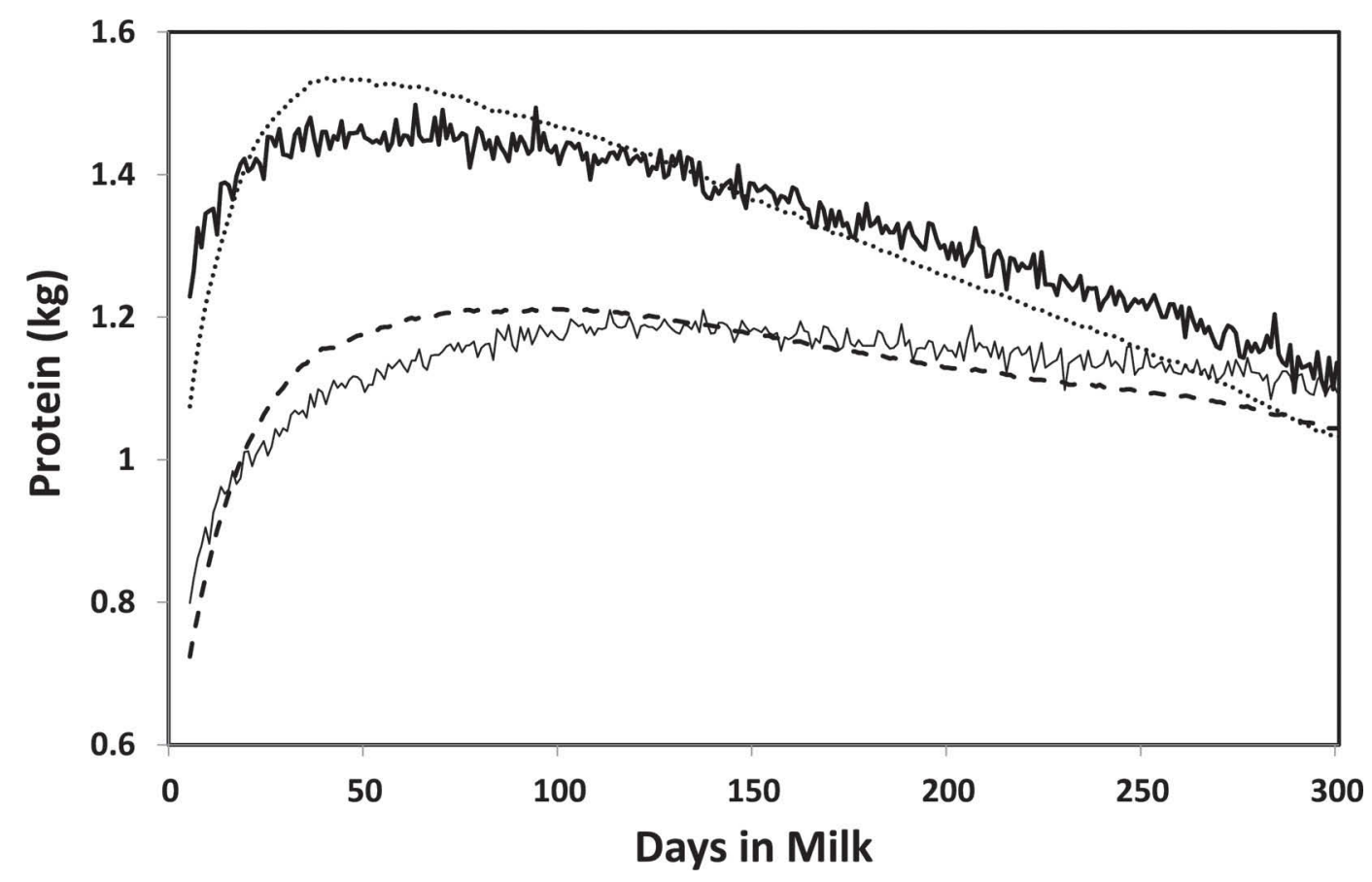

Figure 3. Mean first- and second-parity lactation curves for protein production by monthly and daily records. First-parity monthly records, light solid line; first-parity daily records, dashed line; second-parity monthly records, heavy solid line; second-parity daily records, dotted line. 


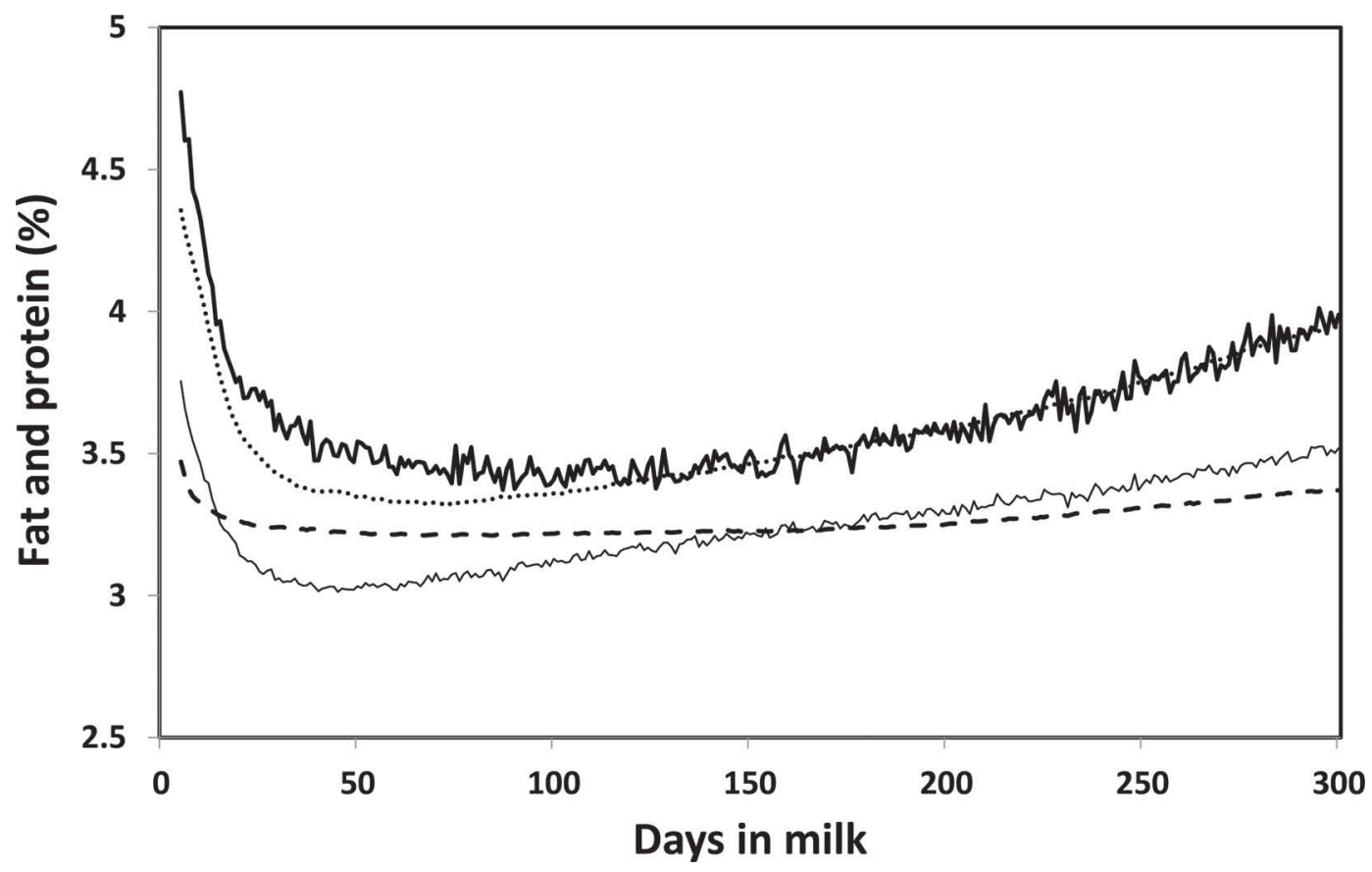

Figure 4. Mean first-parity lactation curves for fat and protein percentage by monthly and daily records. Fat percentage monthly records, heavy solid line; fat percentage daily records, dotted line; protein percentage monthly records, light solid line; protein percentage daily records, dashed line.

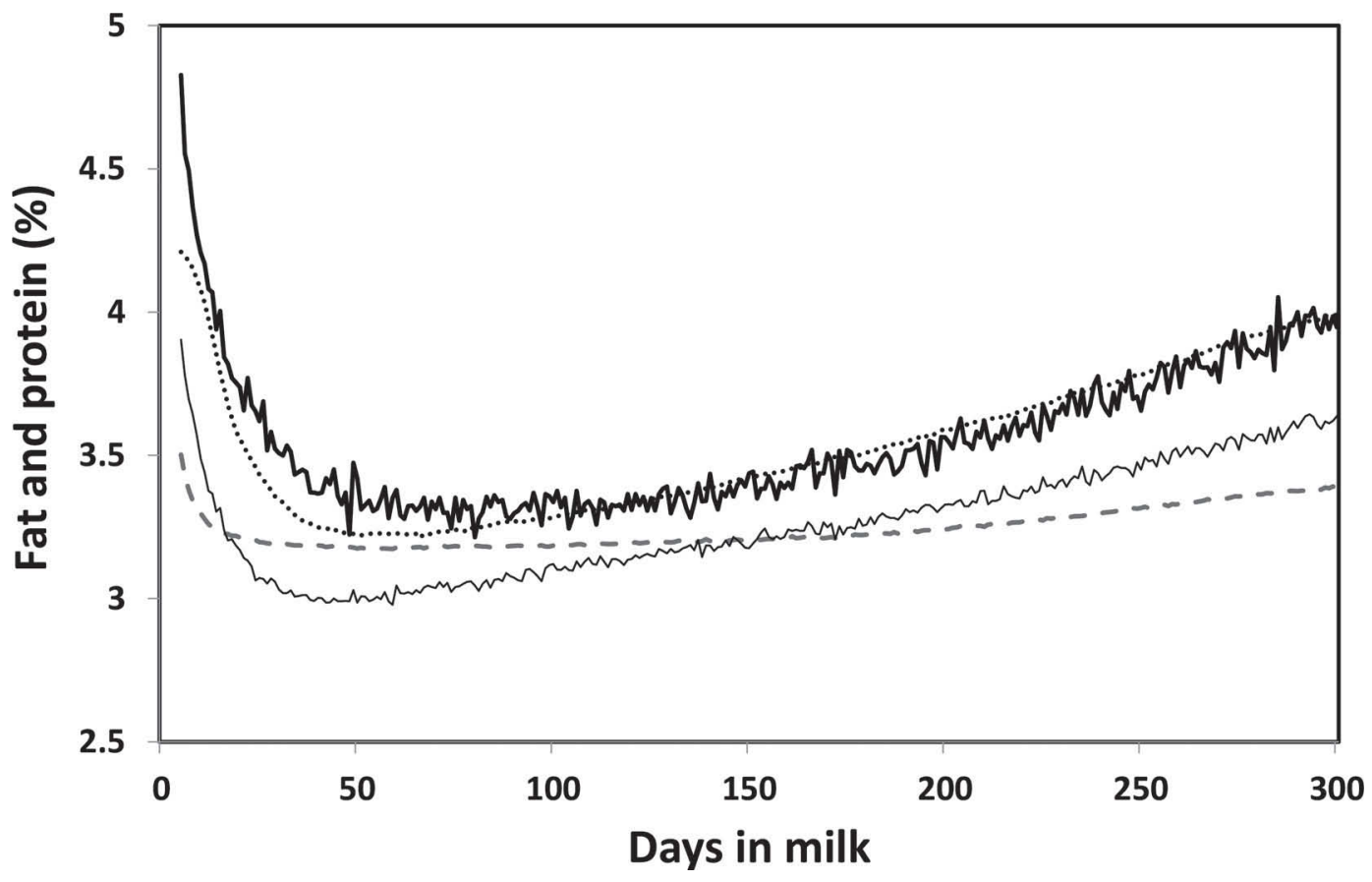

Figure 5. Mean second-parity lactation curves for fat and protein percentage by monthly and daily records. Fat percentage monthly records, heavy solid line; fat percentage daily records, dotted line; protein percentage monthly records, light solid line; protein percentage daily records, dashed line. 
animal model results for this and other commercial diary populations. Weller and Ezra (2004) found firstparity heritabilities of $0.39,0.42$, and 0.34 for milk, fat, and protein production, respectively, in the Israeli Holstein population. Chauhan and Hayes (1991), analyzing the US Holstein population with a sire model, found first-parity heritabilities for milk, fat, protein, and percentages of fat and protein of $0.29,0.31,0.25,0.65$, and 0.61 , respectively. The genetic correlations of milk with yields of fat and protein, and percentages of fat and protein and correlations of fat yield with fat percentage were $0.45,0.79,-0.49,-0.54$, and 0.56 , respectively.

Heritabilities for all traits except protein percentage were higher for lactations computed from daily records, corresponding to our basic hypothesis that more frequent records would yield a more representative measure of a cow's longer-term milk composition. The greatest difference was for fat production, at $8 \%$. However, based on the estimated SE of the heritabilities, none of the differences was statistically significant at even the $5 \%$ level. The SE ranged from 0.025 to 0.076 ; they were generally higher for lactations computed from the monthly records, and higher for the concentration traits, than for the production traits.

As expected, both the genetic and environmental correlations for milk between the 2 methods were almost equal to unity, because, as explained previously, the same records were used for both methods. The lowest genetic correlation between the 2 methods was for protein percentage, at 0.56. Considering each method separately, genetic and environmental correlations among the 3 production traits were higher for the lactations computed from daily records, but lower for the percentage traits. Genetic and environmental correlations between fat and protein percentage were $\sim 0.5$ for the monthly records, but $<0.2$ for the daily records. The genetic correlation of only 0.27 between milk and fat for the monthly lactations in the present study was low compared with the value of 0.45 in Chauhan and Hayes (1991), but Weller and Ezra (2015) found a correlation of 0.31 for the Israeli population on a somewhat selected sample of animals.

The coefficient of determination and root mean squared errors for future production as a function of the number of days before the truncation date used to predict future production are given in Table 5. For lactations computed from test days, only the last testday record before truncation was used. As noted previously, for the analyses based on daily records, all effects included in equation [2] were significant $(P<0.001)$; for the analyses based on the test-day records, all factors were significant, except for $\mathrm{DR} \times \mathrm{DIM}^{2}$ for milk and protein. Coefficients of determination were lower and root mean squared errors were higher for lactations computed from test-day data, compared with the daily records. For the lactations computed from daily records, differences in the coefficients of determination among the 5 alternatives tested were generally small. Coefficients of determination were greatest and root mean squared errors were least if the mean production from the last 2 wk before the truncation date was used to estimate future production, although results for $1 \mathrm{wk}$ before the truncation date were very similar. Further daily results are therefore presented only for the alternative of prediction based on the mean of the last $2 \mathrm{wk}$ before truncation.

Means and SD of predicted first-parity lactation based on truncation dates of the partial lactations for both monthly and daily records are given in Table 6 . For all 3 traits, in both methods actual production was underestimated with truncation after 1 mo in milk, and overestimated with truncation after 2 mo in milk. In both cases, biases were smaller for lactations computed from daily records. With truncation at $>2$ mo in milk, all differences between predicted and actual production were $<1 \%$ of the mean by both methods. As expected, SD increased with months in milk before truncation. Up to truncation at $2 \mathrm{mo}$, SD were lower for lactations estimated from test-day records. Thus, for up to 2 mo in milk, precision was higher for monthly test-day predictors, but accuracy was lower. Surprisingly, at 9 mo, $\mathrm{SD}$ were greater than for the complete lactation in all cases, except for milk by daily recording.

Phenotypic correlations among complete and extended 7,892 first-parity lactations for milk, fat, and protein production computed from test-day records based on the last test date before truncation for each month in milk are given in Table 7 . Correlations were similar for all 3 traits and increased from $\sim 0.7$ for the first record after 15 DIM to $\sim 0.96$ for the first record after 255 DIM. Phenotypic and genetic correlations among complete and extended 7,866 first-parity lactations for milk, fat, and protein production based on the daily means of 14-d production before truncation date are given in Table 8 . The daily phenotypic correlations were higher than the monthly correlations for all 3 traits at all 9 truncation points. The daily genetic correlations were higher than the phenotypic correlations for all 3 traits at all truncation points. With only 30 DIM, genetic correlations ranged from 0.73 to 0.79 for the 3 traits.

Increasing the frequency of sampling reduces random error, but does not correct for systematic biases. The ICAR guidelines (ICAR, 2016) were constructed to ensure sufficient quality of data collection for genetic selection - that is, recording of a single measurement per month. The accuracy tolerance addressed only the 
WELLER AND EZRA

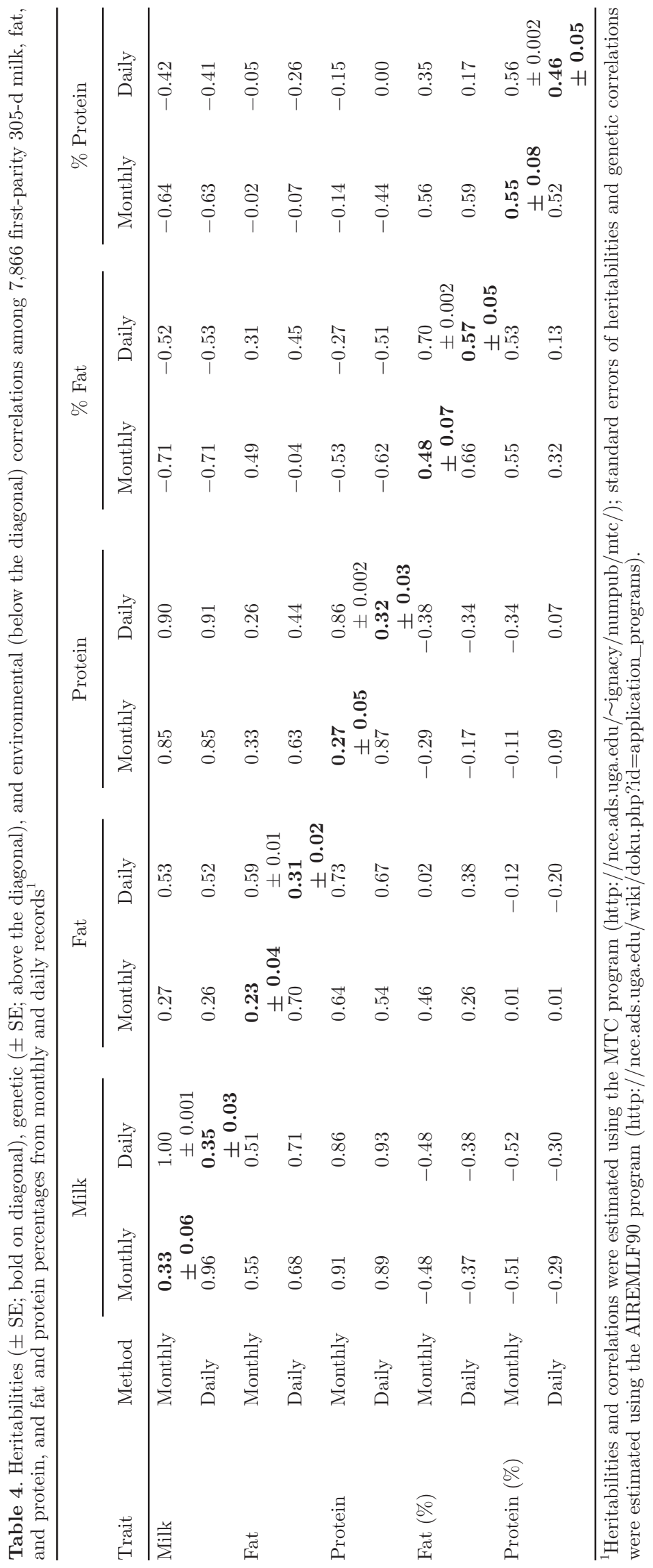


Table 5. Coefficient of determination and root mean square errors (MSE) for production as a function of the number of days before the truncation date used to predict future production ${ }^{1}$

\begin{tabular}{|c|c|c|c|c|}
\hline Method & Number of days & Trait & $\mathrm{R}^{2}$ & Root MSE \\
\hline \multirow[t]{3}{*}{ Monthly } & \multirow[t]{3}{*}{$1 \mathrm{~d}$} & Milk & 0.939 & 631.8 \\
\hline & & Fat & 0.927 & 24.2 \\
\hline & & Protein & 0.944 & 19.3 \\
\hline \multirow{15}{*}{ Daily } & \multirow[t]{3}{*}{$1 \mathrm{~d}$} & Milk & 0.961 & 565.7 \\
\hline & & Fat & 0.956 & 20.8 \\
\hline & & Protein & 0.959 & 18.8 \\
\hline & \multirow[t]{3}{*}{$2 \mathrm{~d}$} & Milk & 0.963 & 547.3 \\
\hline & & Fat & 0.960 & 19.9 \\
\hline & & Protein & 0.961 & 18.2 \\
\hline & \multirow[t]{3}{*}{$1 \mathrm{wk}$} & Milk & 0.965 & 532.5 \\
\hline & & Fat & 0.963 & 19.0 \\
\hline & & Protein & 0.964 & 17.6 \\
\hline & \multirow[t]{3}{*}{$2 \mathrm{wk}$} & Milk & 0.965 & 532.3 \\
\hline & & Fat & 0.963 & 19.0 \\
\hline & & Protein & 0.964 & 17.5 \\
\hline & \multirow[t]{3}{*}{$1 \mathrm{mo}$} & Milk & 0.964 & 545.4 \\
\hline & & Fat & 0.962 & 19.1 \\
\hline & & Protein & 0.963 & 17.7 \\
\hline
\end{tabular}

${ }^{1}$ Only records on or before the truncation date were used to predict lactation production after the truncation date.

added error of the milk sampling procedure to the required accuracy of the inline device. To date, ICAR has not set guidelines for the required accuracy of daily recording systems.

Kaniyamattam and De Vries (2014) have also raised the possibility of systematic biases among cows. If this was the case, then heritabilities should be lower for lactations computed from daily records. If a specific cow is biased upward, there is no reason to assume that the cow's relatives would also have the same bias. Of course, merely demonstrating that one method has higher heritability does not prove that the records are more accurate. Similarly, bias among cows should also adversely affect the ability to predict future production from a partial lactation. In our results, heritabilities were higher for lactations computed from daily records for all traits, except for protein percentage, but none of the differences were significant $(P<0.05)$. Partial lactations computed from daily records predicted future lactation more accurately than corresponding partial lactations computed from monthly records. With respect to predicting future lactation production from partial lactations, both methods were biased if the partial lactation was $<90$ DIM; predicted lactations computed from monthly records were more biased, but precision was greater, as indicated by the SD of the predictions.

Over the last 2 decades, several countries have replaced lactation models with monthly test-day models for routine genetic evaluation of milk production traits (e.g., Stanton et al., 1992). That is, the dependent variable is production on each monthly test day rather

Table 6. Means $\pm \mathrm{SD}$ of predicted first-parity lactation $(\mathrm{kg})$, based on truncation dates of the partial lactations computed from monthly and daily records

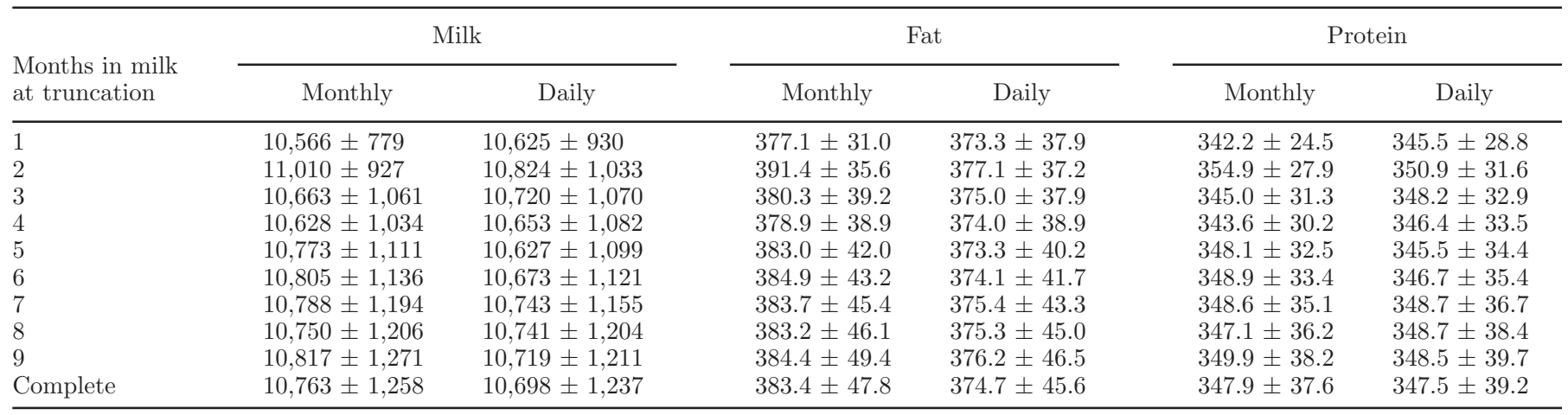


Table 7. Phenotypic correlations among 7,892 complete and extended first-parity lactations for milk, fat, and protein production from test day records based on the last prior monthly test date for each month in milk

\begin{tabular}{|c|c|c|c|c|c|c|c|c|c|}
\hline \multirow[b]{2}{*}{ Trait } & \multicolumn{9}{|c|}{ Mean DIM at truncation } \\
\hline & 37.4 & 60.0 & 94.1 & 121.0 & 153.2 & 181.4 & 212.7 & 241.5 & 266.5 \\
\hline Milk & 0.69 & 0.76 & 0.78 & 0.88 & 0.91 & 0.93 & 0.95 & 0.95 & 0.96 \\
\hline Fat & 0.67 & 0.75 & 0.79 & 0.87 & 0.91 & 0.93 & 0.95 & 0.95 & 0.96 \\
\hline Protein & 0.70 & 0.76 & 0.78 & 0.87 & 0.90 & 0.92 & 0.94 & 0.94 & 0.95 \\
\hline
\end{tabular}

than total lactation production. The main advantages of these models are their ability to more correctly weight complete versus incomplete lactations. With 10 test days per lactation, the number of records in a monthly test-day model is approximately 10 times the number of records in a lactation model. However, if daily records are available, then the number of records included in a "daily production" model would be $\sim 300$ times that of a lactation model. If daily recording becomes widespread, monthly test-day models would no likely longer be appropriate, and new methods must be developed to accurately weight partial versus complete lactations for genetic evaluation.

Even if daily records are slightly less accurate for computing total lactation production, this method can still be preferred if it results in a significant cost reduction (i.e., fewer milk inspectors). It is unlikely that the DHIA sample collection system could be completely eliminated for 2 reasons: the daily recording system still must be calibrated several times during the lactation, based on a more accurate method of estimation; and the daily recording system at present does not estimate SCC, which is an economically important trait in all modern selection indices (Miglior et al., 2005).

This study is clearly not the "last word" on evaluating the daily recording system. Evaluations of larger samples over a longer period will yield more accurate information and allow for comparison across different lactations of the same cows. Further study is also required to determine the optimal interval between calibrations for AfiLab meters.

\section{CONCLUSIONS}

The main objective of the present study was to test the hypothesis that a combination of more frequently but less accurately analyzed milk components should give a more representative measure of a cow's longerterm milk composition than a DHIA sample taken once per month. Although our hypothesis was apparently validated based on the heritability estimates and the ability of partial lactations to predict future production, systematic biases with respect to stage of lactation in both parities was troubling. The lactation curves for fat percentage from daily records were lower with low DIM, but almost equal to the monthly records after 125 DIM. Automatic daily recording overestimated protein percentage before 150 DIM and underestimated protein percentage in the second half of the lactation. Further study is required to compare results of individual cows in multiple lactations, and to determine the optimal interval between calibrations for AfiLab meters.

\section{ACKNOWLEDGMENTS}

This research was supported by a grant from the Israel Dairy Board. We thank Ignacy Misztal (University of Georgia, Athens) for use of MTC, Kristen L. Parker Gaddis (Beltsville Agricultural Research Center, Agricultural Research Service, USDA, Beltsville, MD) for help in running AIREMLF90, Afimilk (Kibbutz Afikim, Israel) for providing the AfiLab data, and Marina Giphas (Israel Cattle Breeders' Association, Caesaria

Table 8. Phenotypic and genetic correlations among 7,866 complete and extended first-parity lactations from daily records for milk, fat, and protein production based on the daily means of $14 \mathrm{~d}$ of production before truncation date

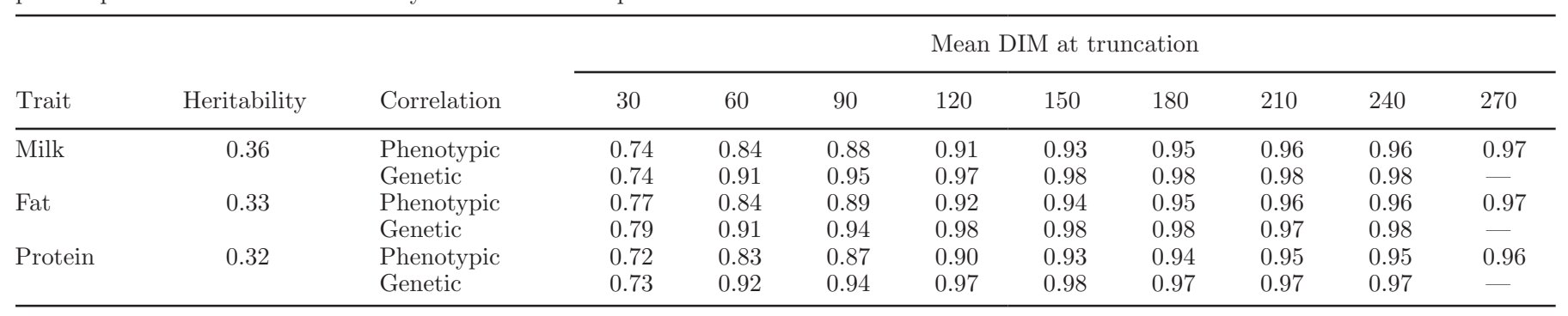


Industrial Park, Israel) for explanation of the ICBA laboratory system.

\section{REFERENCES}

ICAR, International Committee for Animal Recording. 2016. ICAR recording guidelines. Accessed Aug. 31, 2016. http://www.icar. org/wp-content/uploads/2016/03/Guidelines-Edition-2016.pdf.

Bar-Anan, R., J. I. Weller, and B. Reichman. 1984. [The development of the lactation after freshening and during the peak production period.] Meshek Habakar Vehahalav 189:31-34. [In Hebrew].

Bucek, P., K. Zottl, J. Kyntäjä, F. Miglior, H. Leclerc, J. van der Westhuizen, K. Kuwan, Y. Lavon, K. Haase, C. Trejo, D. Radzio, Z. Elsaid, and M. Oudah. 2015. World-wide trends in milk-recording in cattle. ICAR Technical Workshop, Krakow, Poland. ICAR, Rome, Italy.

Chauhan, V. P. S., and J. F. Hayes. 1991. Genetic parameters traits for Holsteins for first lactation milk production and composition using multivariate restricted maximum likelihood. J. Dairy Sci. 74:603-610.

De Boer, J. A., J. I. Weller, T. A. Gipson, and M. Grossman. 1989. Multiphasic analysis of milk and fat yield curves of Israeli Holsteins. J. Dairy Sci. 72:2143-2152.

Ginsberg, R. 2015. The Israeli Holstein cow: A world leader in milk yield. Hoard's Dairyman Oct 25:676-677.

Kaniyamattam, K., and A. De Vries. 2014. Agreement between milk fat, protein, and lactose observations collected from the Dairy Herd Improvement Association (DHIA) and a real-time milk analyzer. J. Dairy Sci. 97:2896-2908.

Kaylegian, K. E., J. M. Lynch, G. E. Houghton, J. R. Fleming, and D. M. Barbano. 2006. Modified versus producer milk calibration: Mid-infrared analyzer performance validation. J. Dairy Sci. $89: 2833-2845$.

Klei, B. 2008. Approximate variance for heritability estimates. Computational Genetics, Western Psychiatric Institute and Clinic, University of Pittsburgh Medical Center. Revised by S. Tsuruta. Accessed Aug. 31, 2016. http://nce.ads.uga.edu/ shogo/html/ research/AI_SE.pdf.

Liu, Z.,, F. Reents, Reinhardt, and K. Kuwan. 2000. Approaches to estimating daily yield from single milk testing schemes and use of a.m.-p.m. records in test-day model genetic evaluation in dairy cattle. J. Dairy Sci. 83:2672-2682.

Miglior, F., B. L. Muir, and B. J. Van Doormaal. 2005. Selection indices in Holstein cattle of various countries. J. Dairy Sci. 88:12551263.

Pavel, E. R., and C. Gavan. 2011. Seasonal and milking to milking variations in cow milk fat, protein and somatic cell counts. Notulae Scientia Biologicae 3:20-23.

Quist, M. A., S. J. LeBlanc, K. J. Hand, D. Lazenby, F. Miglior, and D. F. Kelton. 2008. Milking-to-milking variability for milk yield, fat and protein percentage, and somatic cell count. J. Dairy Sci. 91:3412-3423.

Rotz, C. A., C. U. Coiner, and K. J. Soder. 2003. Automatic milking systems, farm size, and milk production. J. Dairy Sci. 86:41674177.

Schmilovitch, Z., A. Mizrach, A. Hoffman, H. Egozi, and Y. Fuchs. 2000. Determination of mango physiological indices by near-infrared spectrometry. Postharvest Biol. Technol. 19:245-252.

Stanton, T. L., L. R. Jones, R. W. Everett, and S. D. Kachman. 1992. Estimating milk, fat, and protein lactation curves with a test day model. J. Dairy Sci. 75:1691-1700.

Tsenkova, R., S. Atanassova, K. Itoh, Y. Ozaki, and K. Toyoda. 2000. Near infrared spectroscopy for biomonitoring: Cow milk composition measurement in a spectral region from 1,100 to 2,400 nanometers. J. Anim. Sci. 78:515-522.

Tsenkova, R., S. Atanassova, K. Toyoda, Y. Ozaki, K. Itoh, and T. Fearn. 1999. Near-infrared spectroscopy for dairy management: Measurement of unhomogenized milk composition. J. Dairy Sci. $82: 2344-2351$.

Weller, J. I. 1988. Inclusion of partial lactations in the genetic analysis of yield traits by differential weighting of records. J. Dairy Sci. 71:1873-1879.

Weller, J. I., R. Bar-Anan, and K. Osterkorn. 1985. Effects of days open on annualized milk yields in current and following lactations. J. Dairy Sci. 68:1241-1249.

Weller, J. I., and E. Ezra. 2004. Genetic analysis of the Israeli Holstein dairy cattle population for production and non-production traits with a multitrait animal model. J. Dairy Sci. 87:1519-1527.

Weller, J. I., and E. Ezra. 2015. Environmental and genetic factors affecting cow survival of Israeli Holsteins. J. Dairy Sci. 98:676-684. 